\title{
HET VERLEENEN VAN GELDELIJKE HULP BIJ DEN AANKOOP VAN VEE.
}

In har "verslag over de nitkomsten van hel onderzoek naar den toestand van den landbouw in Nederland", uitgebracht 4. Juni 1890 , klaagt de Landbouwcommissie die bij K. B. van 18 Sept. 1886 No. 28 was benoemd tot het instellen van dat onderzoek, dat het credietwezen ten platten lande uitermate oubevredigend is. Dit geldt voornamelijk van het personeel crediet, zegt zij, en dringt dit nader aan met deze woorden: "Algemeen is de klacht over gebrek an kapitaal: gebrek aan kapitaal voor verbeteringen, gebrek aan bedrijfskapitaal, gebrek aan de noodige kas om in tijdelijke behoeften te vonrzien. Vandaar weder te weinig vee, onvoldoende bemesting, of wat nog erger is, gedwongen verkoop van producten of vee op onvoordeelige tijdstippen, zelfs verkoop van mest of werktuigen of het verkoopen van de beste exemplaren van het vee, terwijl elders het gebrek ann contanten de landbouwers afhankelijk makt van opkoopers of speculanten, die de markt weten te beheerschen." 1)

Moge al, sedert de Landbouwcommissie haar resultaten wereldkundig maakte, veel geschied zijn dat haar thans misschien aanleiding zou geven haar oordeel eenigermate te wijzigen, zoo is, wat het speciale punt aangaat waarmede wij ons bezig te houden hebben, - den a n koop vau vee-, nog alles wel bij het oude gebleven.

Nieuwsgierig naar den tegenwoordigen toestand van de credietverschaffing voor den veeankoop, zocht ik voor verschil-

1) Zie "Uitkomsten van het onderzoek naar den toestand van den Landbouw in Nederland» ingesteld door de commissie voornoemd, deel IV. p. 31 en 33. 
lende deelen van ons land inlichtingen bij hen, die ik kon nagaan dat het best van de locale gesteldheid op de hoogte waren; hunne vriendelijke hulp stelde mij in staat mij over dien toestand eenigszins een beeld te vormen, waarbij ik tot de conclusie kwam, dat dit terrein nog schier geheel braak ligt.

Dat er misbruiken bestan die algemeen verspreid en dicp ingeworteld zijn, dat de kleine boer of de boerenarbeider (e op hen heb ik hier voornamelijk hot oog) als regel blootgesteld ziju aan de plunderzucht van woekeraars wanncer zij zich een stuk vee willen aanschaffen, is mij noch uit de mij persoonlijk verstrekte inlichtingen noch uit de "Uitkomsten" geblekeu; wel moge men van hier en daar hooren verluiden dat niet alle handel geheel in den haak is en dat meer dan billijk is wordt geprofiteerd van de economische positie van den boer, doch nauwkeurige mededeeling van bepaalde feiten en cijfers die met meerder of minder juistheid in staat zoudeu kunnen stellen zich over den omvang dier mishruiken een, natuurlijk altijd approximatief, juist oordeel te vormeu lrcb ik niet in de "Uitkomsten" kunnen vinden; zij werden mij cvemmin gegeven in miju particuliere mededeelingen 1). Naar mijne meening zil trouweus de moeilijkheid

1) Men is geneigd, wanneer men van zekere toestanden een ongunstigen indruk verkregen heeft, maar al te vaak naar de feiten die toch de basis van alles behoorden te zijn niet verder te zoeken, indrukken met indrukken te versterken en met een zekere achterdocht hen te ontmoeten die hun oordeel liever opsohorten tot de feiten hun licht hebben laten schijnen. Zoo vormt zich vaak de publieke opinie, die weldra onuitroeibaar wordt. Daarom vermijd ik hier opzettelijk den staf te breken orer menschen en toestanden.

Dat men daarvoor niet met indrukken volstaan kan, maar juist noodig heeft zoowel naar tijd als naar plaats bepaalde feiten, zooveel mogelijk ook quantitatief te benaderen, is een waarheid die op uitnemende wijze in het licht werd gesteld door Dr. G. SchnapperArndt «Zur Methodologie sozialer Enquêten» (Frankfurt 1888) naar aanleiding van de enquête over den woeker op het platte land in Duitschland in 1886 en 1887 ingesteld door den Verein für Socialpolitik. De «Fragebogen», door dien Verein opgesteld - en waarbij die onzer Landbouwcommissie (deel IV. Bijlage B) allergunstigst 
niet in het bestaan van voor den boer nadeelige vormen van credietverstrekking, maar hierin dat voor deze behoefte, den aankoop van vee, den boer, althans den kleinen, schier in het geheel geen voorziening - slecht noch goed - wordt geboden. Wel wordt in verschillende streken van het land op verschillende wijzen crediet (in ruimeren zin) verleend voor den veeaankoop, naar behalve dat die vormen niet altijd van dien aard zijn dat algemeene toepassing aanbevelenswandig zon schijnen, heeft de $\mathrm{kleine}$ boer en de arbeider van die hulp toch in den regel nooit profijt.

Waaraan dit is toe te schrijven zal van zelf duidelijk worden bij de bespreking dier vormen van credietverstrekking waartoe ik thans overga. Ik zal daarbij gebruik maken van de opgaven voorkomende in de Verslagen over de "typegemeenten" (Uitkomsten, deel I-III) en van de mij onlangs verstrekte inlichtingen.

De eenvoudigste manier waarop men den boer of aijn arbeider in staat stelt zich vee aan te schaffen dat hij uit eigen middelen niet koopen kan, is natuurlijk het geven van crediet (in engeren zin). Die manier behoeft niet altijd voor hem onvoordeelig te zijn, maar is het toch, voor zoover het mogelijk is achter de voorwaarden van het contract te komen, volgens de eensluidende herichten meestentijds. Ik zeg: voor zoover het mogelijk is achter de voorwaarden te komen; want dergelijke contracten worden vaak met veekoopers en dergelijken gesloten, zelden of nooit met credietinstellingen; en de boer zelf verkeert dan dikwijls in zoodanige omstandigheden dat hij zijn financiëele operaties liever niet aan de klok hangt. In de "Uitkomsten" vond ik ten aanzien der gemeente Voorst ver-

afsteekt - had tot het bewandelen van den slechten weg maar al te veel uitgelokt. De resultaten verdienden dan ook niet gelijk later door Thiel, den leider der enquête zelf erkend werd (Verhandlungen 1889 p. 45) - , den naam van wetenschappelijk, d. w. z. juist, althans voor hunne juistheid waarborgen verschaffend. Dat dit ook niet beoogd werd, en dat het bij de enquête niet om quantitatieve vaststelling doch voornamelijk on de kennis der vormen van den woeker te doen was, was een verdediging die Th. weinig kon baten, al was het alleen maar om den aanhef van den Fragebogen. 
meld dat daar wol tegen 12 ì 13 pCt. crediet gegeven werd. Crediet geven koint 0. a. ook voor in Sloten, Berkel en Rodenrijs enz. Veel meer dan "on dit's" geven die berichten wel niet. Alleen dat men, daargelaten den omvang dier verschijnselen, hun aanwezigheid als bewezen mag aannemen, wordt toegelaten door het feit dat die berichten, als regel ierler over een enkele gemeente loopende, afkomstig zijn van menschen die de toestanden nit eigen anschouwing kennen.

Bedenkelijker wordt deze credietverstrekking wanneer wat vooral in het voorjaar pleegt te geschieden - vee zoogenaamd op boelhuizen wordt gekocht, waarbij dan vaak een zesmaandscrediet gegeven wordt.

Kleinere boeren, aldus schrijft unen uit den Bommel (Uitkomsten LXVII, p. 7) bezwijken dikwijls voor de verzoeking om door op dergelijke wijze vee te koopen en à comptant van de hand te zetten, geld op handen te krijgen; en zoo daar als elders is deze operatie slechts een onderdeel van het stelsel var, zooals men het in Zevenbergen uitdrukte "den eeven zak met den anderen te lappen."

Dat hier kwade praktijken niet uit konden blijven, ligt voor de hand, Zoo kwamen in Friesland indertijd die vechoclgoeden veel voor en werd wel, - de verkooping geschiedde in een herherg - de plechtigheid veel later dan het aingekondigde uur geopend, "opdat, naar men wil," (aldns mijn bcrichtgever) "de koopers door drankgebruik ietwat opgewonden zouden zijn." Gelukkig schijnen die boeldagen, dank zij de werking der matschappij van Landbouw in die provincie, veel minder voor te komen en daarmede een misbruik gekeerd te zijn dat noodwendig een kanker voor de welvaart moest worden. ')

1) In Duitschland meende men dergelijke misbruiken slechts door het ingrijpen der wet te kunnen keeren. Bij de wet van 19 Juni 1893 , die een belangrijke uitbreiding geeft an de toen reeds bestaande maatregelen tegen den woeker, wordt aan $\S 367$ van het Strafivetboek een nieuw $\mathrm{N}^{\circ}$. toegevoegd, waarbij met geldboete bedreigd wordt "wer den über das Abhalten ron öffentlichen Versteigerungen und über das Verabfolgen geistiger Getränke vor und bei öffentliche Versteigerungen erlassenen Anordnungen zuwiderhandelt.» 
Het karakter van winstbejag dragen ook nict zelden die contracten waarbij de boer van den koopman zijn vec op crediet koopt en dan tevens bepaald wordt dat de boer aan zijn credietgever het vee weer zal verkoopen. (Zie b.v. Mijdrecht en vooral Moerendaal.) Niet altijd behoeft dit tot misbruiken aanleiding te geven en men mag zich ook niet verhelen dat in menig geval de veehandelaar, ook al draagt hij niet het risico van het $\mathrm{vee}$, geen onaanzienlijk gevaar loopt van zijn geld nimmer terug te zien, en in den waren zin rles woords op hoop moet leven. Doch díur zal het immoreele der contracten m. i. boven twijfel verheven zijn, waar, gelijk wel in Friesland heet te geschieden, de koopman ten eerste den boer voor 6 maanden tegen $10 \mathrm{pCt}$. crediet geeft en dan nog op het eind van den termijn eigenmachtig de som bepaalt waarvoor hij het vee terugneemt. Bij dergelijke contracten is de boer aan handen en voeten gebonden: aan een ander verkoopen kan, althans zal hij niet, het vee gaat dus niet ter markt en de eerlijkheid van den veehandelaar is voor hem de eenige bescherming tegen uitplundering. Ook in Zuidholland schijnt dit zgn. "koopen op obligatie" vrij verspreir. Vce dat van laarkt tot markt is vervoerd, en waarin "de pot zit," d. w. z. dat vatbaar is voor ziekte wegens geleden gebrek en ontbering, wordt daar aan den hulpbehoevenden landbouwer op de vermelde voorwaarden verkooht, en dit is niet zelden aanleiding dat de veehandelaar ten koste van den boer profiteert en deze bij hem in het krijt raakt.

Toe te juichen zijn natuurlijk die gevallen waarin de grondeigenaar aan zijn pachter geld schiet voor den aankoop van vee, mits ook gene de hulp die hij dezeu verleent niet doe overslaan in een steun die verzwakt. Menschenkennis en zaakkennis ziju hier onmisbar om niet in misplaatste of verkeerd aangewende naastenliefde vele belangen te schaden. Doch dat dergelijke hulp, die, verleend door den grondeigenaar, niet zelden ook diens eigen belangen kan dienen, zoo weinig voorkomt, en wel bijna zonder uitzondering geheel achterwege blijft waar zij gevraagd wordt van hem die tot den boer in geenerlei betrekking staat, mag zijn oorzaak wel vinden in het gebrekkige verhaalsrecht dat de wet en de omstandigheden aan den geldschieter op vee geven. Doch over dit punt aanstonds. 
Nog op andere wijzen wordt hulp verleend voor de aanschaffing van vee. Loo even zagen wij den boer schuldenaar worden van een zekere som tegenover den geldschieter en eigenaar van het met dat geld gekochte vee. Doch er zijn ook contracten mogelijk waarbij hij die de hulp verstrekt eigenaar blijft, terwijl de boer enkel houder wordt.

Zeer zeldzaam vond ik hier te lande den vorm vall het afbetalingscontract. Bij wijze van uitzonderiug staat er iets van vermeld in de "Uitkomsten" in het verslag over de gemeente Gulpen (deel III, XCV p. 4). Toch schijnt dit contract in Duitschland veel gebruikt te worden en, is het zooals hieronder blijken zal, de basis waarop naar mijne meening, voor dit onderdeel van het landbouwcrediet veel goeds kan worlen gedaan. Op zich zelf echter kan niet worden ontkend dat het afbetalingscontract, zuiver als Geschäft opgevat, zeer bezwarend kan zijn voor den boer en hem an de mogelijkheid van vele onbillijkheden blootstelt.

Andere vormen waaronder de boer aan vee geholpen wordt terwijl de andere partij er eigenaar van blijft, zijn de opstalling en de halfbouw.

De opstalling omvat soms enkel wat het woord zelf nangeeft, soms ook komen er elementen bij die haar maken tot een tusschending tussehen de eigenlijke opstalling en de halfbouw.

De halfbouw komt veel overeen met wat de Duitschers Vieheinstellung of Viehverstellung noemen, een contract met eindelooze variatiën maar dat hierop neerkomt (in den regel althans) dat de boer het vee waarvau hij den halven prijs betaalt, op stal krijgt daardoor recht heeft op de mest en op een deel vau de jongen, terwijl de eigenaar van het vee het andere deel der jougen ontvangt, en soms ook de keus heeft om het vee aan den boer te laten en dezen dan te doen betalen hetgeen hij vau den prijs nog niet betaalde in verband met de vermeerderde waarde van het vee. Of dit contract deu stempel van woeker draggt, langt geheel van omstandigheden af: in Duitschand wordt er over geklaagd '); hier vernam ik weinig klachten, vermoedelijk hierom, omdat $1^{\circ}$ de halfbouw, naar

1) Zie Fassbender: die ländlichen Spar- u. Darlehnskassenvereine 1890, en Bäuerliche Zustäude in Deutschland in 1883 uitgegeven 
het mij toeschijut in ous land, niet zoo uitgebreid is, als de Vieheinstellung in die Duitsche streken war kleine boeren de meerderheid vormen, en $2^{\circ}$ bij onze opstalling, naar al mijne opgaven luideu, het risico - "de noed" (nood) zooals men in Frieslind zegt - nêerkomt op het hoofd van den eigenan.

IIet volgende schreef mij een mijner vrienden van den Nonrderzoom der Veluwe: "Het gebeurt nu en dan dat iemand die geen gelegenheid heeft tot het houden van vee, een of meer beesten bij een ander op stal heeft. Dit ziju dan lieden die geen geld hebben om een beest te koopen, maar zich verbinden het dier te verzorgen en te voederen, waardoor zij de beschikking krijgen over de melk en de mest. Is de koe gust "(drachtig)" ook dan moet degene die het dier op sial heeft, het voeden, maar het kalf is voor hem: worden er twee kalveren geboren, dan is er een voor den eigenaar tenzij

door den Verein für Socialpolitik. Belangrijke mededeelingen zijn ook te vinden in de verslagen der Hessische landwirtschaftliche Genossenschaften", zie bv. bl. 4 en 5 van het verslag orer 1891 , uitgebracht op het $31^{\mathrm{e}}$ congres te Mainz (Darmstadt Herbert 1892). Ook verschaffen de rapporten in "Wucher auf dem Lande» dat ik hierboven beprak, gegerens al schijnen ook deze hier evenmin als op andere punten volkomen vertronwbaar (zie Schnapper Arndt t. a. p. p. $12,2^{e}$ noot). In het rapport over de omstreken van Trier, dat overigens veel aanleiding gegeven heeft tot gegronde kritiek (zie ook Zuns: der Wucher a. d. Lande eine Kritik des Fragebogens» enz. Franlif. 1888), - wordt o. a. op bl. 169 en 170 in extenso een contract met cle omstandigheden waaronder het gesloten werd, medegedeeld dat op de dnidelijkste wijze in het licht stelt hoe nadeelig vonr len boer zulke overeenkomsten kunnen werken, en men vraagt zich charlij alleen nog af of en, zoo ja hoe de boeren er toe komen bij voortduring zich aan dergelijke contracten te wagen.

Dezelfcle wet die ik boven aanhaalde, gaf onder den drang der klachten tegen dezen vorm van bandeldrijoen, aan $\$ 35$ der Gewerbeordnung deze uithreiding dat voortaan ook «der gewerbsmässige Betrieb der Viehverstellung (Viehpacht)», gelijk ook de veehandel in het algemeen, verboden kan worden \&wenn Thatsachen vorliegen, welche die Unzuverlässigkeit der Gewerbetreibenden in Bezng auf diesen Gewerbebetrieb darthun.»

Ik deel deze bepaling mede enkel om hare merkwardigheid, niet omdat ik har zon durven goedkeuren. 
natuurlijk een ander accoord gutrofleu is. De eigenaar heeft echter altijd het recht het dier te verkoopeu; gewoonlijk zal hij daartoe overgaan, wanneer de koe, die als jong beest op stal is gebracht, genoeg in waarde is gestegen om hem in verband met de marktprijzen een behoorlijke winst te greven. Meu noemt dit hier: "een koe op half gewin hebben." Juist dezer dagen kwam mij een geval ter ooreu dat iemand den eigenaar gevraagd had het dier terug te nemen, want de schade was meer dan de winst geweest. Dit hangt echter van allerlei wisselende omstandigheden af: goed of slecht grasjaar, duur of goedkoop hooi enz."

Ongeveer op dezelfde wijze gaat het in sommige streken van Friesland, waar intusschen, - en dit mag ook van andere deelen van Nederland gezegd worden, $-{ }^{1}$ ) niet zelden de opstalling niet dient om te helpen hem die het dier op stal neemt, doch hem die het geeft. In vele gevallen toch geeft de eigenaar van de koe, wanneer hij geen gelegenheid viudt een stukje land te huren en het beest te laten weiden, zijn vee aan een ander op de stal of in de weide, waarvoor hij natuurlijk betalen moet. ${ }^{2}$ )

Ook in Zuidholland geschiedt wel wat zooeven van de Veluwe gezeyd werd. Doch hier is men er niet mede tevreden, omdat de koopınan de prijs van zijn dier zelf bepaalt, de meerdere of mindere opbrengst door opstaller en eigenaar gedeeld wordt, en deze laatste zich het recht voorbehondt het vee ten allen tijde weg te haleu zoodat hij den boer in handen heeft. Daarentegen schijnt de opstalling zooals die in Zuidholland bestaat doch, ten gevolge der gewijzigde behandeling van het land en de producten, allengs verdwijnt, die afkeuriug viet te verdienen. Dit toch gaat aldus. "Wanneer vaarzen worden opge-

1) Zie br. de «Uitkomsten» over Haarlemmermeer: II $n^{0}$. XLI bl. 11.

2) Voor dit doel aangewend ziet men de opstalling of Viehverstellnng zich reeds in de $S^{e}$ eeuw ontwikkelen. De boeren waren in die tijden verplicht een deel van het vee hunner heeren bij zich te laten overwinteren, hetgeen een der gewichtigste factoren van de ontwikkeling van den veestapel in die dagen schijnt geweest te zijn. Zie Yamanoto, die Rinderzucht Deutschlands 1894 bl. 31. 
stald bij bouwboeren, dan krijgen ze alleen stroo tot voedsel waardoor geen groote uitgaven worden geëischt en derhalve een kleine betaling gegeven wordt. Koeien die nog wat melk geven maar spoedig drooggaan en bestemd zijn voor latere vetmesting, krijgen krachtvoeder in lijnkoeken, boonen etc. en dit krachtvoer wordt door den eigevaar vergoed. - De kalfkoeien mits het zijn tijdkoeien (d. w. z. koeien die laat in Maart of in April kalven) staan gelijk met de laatstgenoemde varekoeien. Kalven zij bij den boer af, dan is het kalf voor den greep (d.i. voor den stal, dus voor den boer). Het risico van het afkalven is voor den eigenaar, en, blijft het dier bij hem op stal, dan behoudt hij de melk. Sterft het dier, dan wordt yeen stalgeld of slechts een gerleelte daarvan betald: die regeling stat meestal in verband met de opbrengst van het cadaver." Tot zoover mijn zegsman.

Iets dergelijks als de halfbouw vindt men in Drente met schapen. Deze worden in een soort vau huur afgestaan. Is het contract afgeloopen, dan krijgt de eigenaar of wel een bepaalde som in handen of wel een deel (b.v. de helft) der jongen, terwijl de huurder een zelfde aantal beesten en van gelijke qualiteit aan den verhuurder moet teruggeven als hij ontving.

Vooral deze laatste vorm, maar ook de eerder genoeinde, herinneren aan den bail à cheptel '), met name voor zoover de schapenhuur in Drente betreft aau den cheptel de fer, en wijzen op een gerneenschappelijke afkomst.

'Toch bestaat ten onzent de eigenlijke bajl à cheptel niet. Zooals bekend is onderscheidt de Code (ivil (art. 1800, v. v.) vier soorten. a. De "cheptel simple" laat den verhuurder den eigendom eu geeft hem recht op de helft der jongen, terwijl de huurder de andere helft krijgt maar ook, althans

1) Cheptel (spr. chétel), ook wel in het oud-fransch: catel, catal, chaptel, cattel, is éen woord met het Engelsche cattle, dus vee, en komt van capitale of captale (laag Latijn). In vroeger eeuwen was het vee het roornaamste deel van iemands bezittingen. Tacitus schrijft reeds van het vee der Germanen van zijn tijd: «numero gaudent, eaeque solae et gratissimae opes sunt» al vindt hij ook dat ze het Romeinsche oog weinig bevredigen, want: «ne armentis quidem suus honor ant gloria frontis.» (Germania cap. 5.) 
hij gedeeltelijk verlies, dit voor de helft draggt, wordende het totale verlies mits buiten de schuld van den huurder, door den verhuurder gedragen. b. De "cheptel à moitié" is te vergelijken met een commanditaire vennootschap: ieder brengt de helft der beesten in op gemeeve wiust en verlies, terwijl degeen die als "preneur" optreedt, - men zou hem beheerend vennoot en de andere partij sleepiug partner kunnen noemen - het genot van melk en mest heeft, en het recht vau den auder beperkt blijft tot de helft der wol en der jongen. c. De "cheptel de fer" bestaat tusschen verpachter en pachter en zit eigenlijk aan de landpacht vast. De pachter wordt hier evenıiu als in het geval sub a. eigenaar, maar toch dragt hij het risico der kudde: hij moet een zelfde aautal beesten van gelijke soort op het einde der pacht achterlaten als hij ontving en hij moet bijbetalen wat ontbreekt. Vandaar dat men spreekt van bêtes de fer, immers het beslag "ne peut nourir à son seigneur"; een spreekwijze die men ten onzent in het "ijzeren vee sterft niet" en in Duitschland in den Eisern-Viehvertrag terugvindt. ') d. De "cheptel improprement dit", heeft plaats wanneer een of meer losse beesten worden opgestald, in welk geval de eigenaar alleen recht verkrijgt op de jongen.

Den oneigenlijken cheptel vindt meu ten onzent, zooals gebleken is, wel; ook, bij uitzondering, deu cheptel de fer; maar de cheptel simple en die à moitié komen niet voor. Om dic reden wilde men in 1838 teu onzent aan een regeling niet aan. Het groote verschil tusschen die beide contracten en wat men ten onzent ziet, ligt vooral in de regeling van het risico, die in ons land nooit op hein die bloot gebruiker is schijnt afgewenteld te worden.

Intusschen, het heet dat ook in Frankrijk de bail ì cheptel allengs verdwijnt. Men geeft als reden op de beperkende bepalingen die de wet aan dit contract stelt ${ }^{2}$ ).

1) Het Alg. Pruis. Landrecht I. $21 \S 474$ V. bepaalde dat de pachter van den hem toebehoorenden inventaris, het vee incluis, het risico draagt, en dat hetzelfde gold, "wenn der Pushter das Inventarium als eisern übernommen hat.»

2) Zie Mr. F. S. van Nierop. Europeesch Landbouwcrediet. Gidls 1885 p. 439.

ECon. 1897. 
Marcadé 1) motiveert die beperkingen der contractvrijheid aldus: "L'état de dénûment et d'ignoranes des chepteliers les poussant à souscrire toute espèce de conditions pour obtenir un troupeau par les profits duquel ils espèrent se procurer le pain nécessaire à leur famille, la loi a dû se préoccuper de les protéger contre la rapacité de propriétaires assez inhumains pour spéculer sur leur misère." Zoo bepaalt bv. de wet, dat bij den cheptel simple in geval van gedeeltelijk verlies beide partijen, in geval van totaal verlies $d e$ eigenaar alleen de schade draagt: nu mag niet, bepaald worden dat dit totaal verlies door den boer zal gedragen worden. En wat ziet men nu? Dat in geval van gedeeltelijk verlies (bv. door veeziekte) de boer, om zich van zijn aandeel in het verlies te ontslaan, het overgeblevene aan de besmetting blootstelt en zoo de geheele kudde doet ondergaan. Aldus werd het contract te bezwarend voor den eigenaar en raakte, zoo redeneert men, dientengevolge allengs buiten gebruik. Of niet door een andere, wèl door de wet toegelaten regeling van het risico aan den boer de prikkel zou kunuen ontnomen worden tot dergelijke voor den eigenaar schadelijke praktijken, m. a. w. of op de rekening der beschermende bepaling van Art. 1811 wel alles kan geschreven worden wat men er op zou willen brengen, laat ik hier buiten bespreking. Alleen zou men kunnen vragen - ook met het oog op ons land, waar dan toch de wetgever partijen volkomen vrij liet-of het buiten gebruik komen van deze soort van contracten niet in verband kan staan met de, zoowel met betrekking tot den landbouw als tot de middelen van verkeer, gewijzigde ceconomische toestanden.

Ik heb in het bovenstaande getracht zoo getrouw mogelijk weer te geven welke vormen dienen den boer aan vee te helpen waar eigen middelen niet toereiken. Wanneer ik daarbij anu al die vormen niet mijn onverdeelde sympathie schonk, zoo moet dit vooral in die vormen ${ }^{2}$ ) op zich zelf gezocht worden en niet in de misbruiken die in de praktijk zouden bestan. Zooals ik hierboven reeds zeide, heb ik niet den indruk ver-

1) Explication du Code Napoléon VI p. 552.

3) Van welke, met uitzondering van het credietgeven, de sociale beteekenis dan ook niet groot is. 
kregen alsof inderdaad over misbruiken bij ons onderwerp veel te klagen valt. Alleen zou ik ten aanzien van Limburg een andere meening zijn toegedaan, alwaar ik geloof dat wel vele misbruiken heerschen, hetgeen merkwaardig samenvalt met het oordeel der Landbouwcommissie over die provincie (t.a. $p$. bly. 33), naar welk oordeel de credietwaardigheid der landbouwers, moge die in het algemeen niet achteruit zijn gegaan, in sommige streken, vooral in Limburg, wel is gedaald. Zoo zouden toch de omvang der misbruiken met de credietwaardigheid van den landbouwer tot elkander staan in oingekeerde reden.

De klachten over de onvoldoendheid der credietmidden en de daarvoor niet zelden veroorzaakte schaarsehte vau vee, hourlen naar mijne meening dan ook veel meer verband met het achterwege blijven van geschikte vormen van crediet, dan met slechte praktijten, m. a. w. de fout ligt minder in wat gedaan is dan in wat ongedaan bleef.

De boer en ook zijn arbeider heeft behoefte aan vee, al is het maar een enkele koe of een varken, het zij voor eigen gebruik of voor zijn bedrijf. Vermeerdering van levende have, wie zou het voor hen niet een zegen achten? In de "Uitkornsten" vond ik ergens gewezeu op den gunstigen toestand der boeren-arbeiders die voor zich en hun gezin een varken mestten; en bovendien, wat zou bij trouwe zorg zulk een klein kapitnaltje, in dat varken vertegenwoordigd, niet een rente kumnen dragen, wanneer - ja wanueer de min lat kapitaltije maar eens eerst in zijn hok had!

Maar hoe daaraun te komen? Zich persooulijk wenlen tot de mensehen in de stad is hem onmogelijk, en de lieden vit ziin omgeving zijn niet genegen of in staat an zijn wensehen te voldoen. Hoe gianrne menigeen ook misschien zou kunueu en willeu helpen, de zaak blijft zooals ze was, en er gebeurt niets.

$\mathrm{Nu}$ is op zich zelf het brengen van het geld naar de plaats waar het met vrucht aangewend kan worden, niet zoo groote moeilijkheid. Wanneer andere en werkelijke bezwareu zijn opgeheven, dan ligt in het landbouwbankje of jedere willekenrige vereeniging die als tusschenpersoon wil dienst doen, het ontmoetingspunt tussehen den geldbelegger en den landbouwer. 
Wn die werkelijke bezwaren nu zijn gelegen in de waarborgen die de geldschieter verlangt en recht heeft te verlangen, en die het keuterboertje niet geven kan. Want borgen zal deze wel zelden kunnen geven, of het zijn borgen van dezelfde soliditeit als de zijne; en onderpand heeft de geldschieter in het vee viet, daar immers het met zijn geld gekochte vee eigendom is van den boer on de wet niet toelaat dat het pand blijve in handen van den schuldenaar. De geldschieter kan wel zijn vordering executeeren op het goed van het boertje, waar dan gaat de verpachter nog voor en het is zeer de vraag of bij executie de opbrengst van het boedeltje niet door de executiekosten wordt opgeslokt. Hn dan, loe staat men niet hloot an het gevaar van kwade trouw! Immers kan de boer ongemerkt zijn vee aan een ander verkoopeu, d.w.z. quasiverkoopen en het van dien kooper in bruikleen houden, en van dit alles heel deftige akteu opmaken - zooals toch menigmaal geschiedt zonder dat men daartegen iets vermag! dan heeft men niet alleen nicts om te executcereu, maar heeft nog bovendien veel kosten voor niets gemaakt en loopt men de kans op een proces tot schadevergoeding!

Inderdaad, wie verwondert er zich over dat de menschen liever hun geld in hun beurs houden dan het aan zooveel gevaren bloot te stellen, ook al eijfert men hun voor hoeveel goed zij er mede zouden kunnen doen?

Maar aan den anderen kant, ware het mogelijk den geldschieter de zekerheid te verschaffen waarop hij recht heeft, dan ware de mogelijkheid geopend zonder al te groote opofferingen, of zelfs ter geldbelegging over het geheele land kleine locale instellingen in het leven te roepen die voor hare omgeving van onberekenbaar nut zouden kunnen ziju.

Dat was het vraagstuk dat ik mij tot taak stelde om op te lossen. De aanleiding daartoe vond ik in een verzoek dat tot mij kwam van een soort van bankje dat te Zetten bestaat en dat onder het hestaande reglement met allerlei moeilijkheden te kampen had en kwade trouw vreesde.

Dit bankje gaat uit van de afdeeling Zetten van het Nederlandsch Werkliedenverbond Patrimonium, een afdeeling die met de krachtige en tevens gezonde hulp vau een der meest 
geachte ingezetenen der sireek, reeds velen tol zegen strekte en dit in steeds ruimer mate belooft te doen.

Deze credietinstelling $\mathrm{nu}$ wilde kleine boertjes en arbeiders helpen aan geld opdat zij daarmede een varken zouclen koopen om het te mesten ten einde het later net winst te kunnen verkoopen. Zelf had zij tegen matige rente een som van $f 1000$ opgenomen oin dnaruit de vraag naar voorschotten te voldoen; en zij smaakte het genoegen te zien dat, hoewel zij slechts in kleinen kring werkte, van haar hulp een gretig gebruik gemaakt werd en zij bijna het geheele jaar door verreweg het grootste deel dier som in kleine voorschotjes van f $10-f 25$ had uitstaan. De rente die gevraagd werd was ongeveer 1 pCt. per maand; schijnbaar niet gering, doch waarbij dient in het oog gehouden te worden dat over het ge he ele kapital van f 1000.- een vaste rente moest betaald worden en dat - dit vooral is van belang - het voorschot werd kwijt gescholden wanneer het vee $\mathrm{kwam}$ te sterven. Dat men dan ook in die rente geen bezwaar zag, blijkt uit het ruime gebruik hetwelk ik zooeven zeide dat men van de bank maakte.

Toch ging de zaak niet naar wensch. Men had wel in het reglement gezet dat het met het voorschot anngekoclite vec het eigendom bleef der bank en dat, wanneer bij den boer meer varkens op het hok stonden en een daarvan kwam te, sterven, de bank zou mogen aanwijzen welke van de varkens zij als de hare zou wenschen te beschouwen, - maar men had hooren verluiden dat in rechten met dergelijke bepalingen weinig zou aan te vangen zijn, en hier en daar schenen er voorschotnemers te zijn die rustig de dingen zouden afwachten en geenszins deszins en willens waren hun verplichtingen tegenover de bank na te komen. Het gold hier dus een leveusvraag en in den bestaanden toestand moest noodzakelijk wijziging komen.

Het plan dat ik aan die crediet-instelling voorlegde en dat zij geheel overnam, ga ik thans ontwikkelen. Ik doe dit hier ter plaatse omdat ik, zooals ik reeds zeide, van meening ben dat ook elders in dezclfde richting zou kunnen worden gearbeid, en in de hoop dat deze regelen daartoe eene aansporing mogen zijn.

De grondgedachte van het geheele plan is - behoef ik het nog te zeggen? - den geldschieter eigenaar te maken van het vee dat met zijn hulp gekocht wordt. 
Wanneer ik hier het woord "geldschieter" gebruik, is dit dus ook eigenlijk minder juist. Immers tegelijk geldschieter te zijn en eigenaar van hetgeen met het geschoten geld is aangekocht, is niet mogelijk. Volgens art. 1792 B.-W. wordt de geldleener eigenaur van het geschoten geld en daarmede dus ook van het vee dat hij met dat geld koopt, en de geldsohieter is gewoon schuldeischer, niet eens gredekt door privilegie; daarom kon het onze Zettensche bauk heel weinig baten of ze al in haar reglement schreef dat zij eigenaar zou zijn van het vee met behulp van het voorschot aangekocht.

Maar men kan van den geldschieter voor het vee maken een eigenaar van het vee. En wel op deze wijze. De bank die den boer helpen wil, geeft hem zooveel geld als hij meent noodig te hebben voor den aankoop van bv. een koe of een varken; edoch zij leent hem dit niet, maar stelt het hem ter hand met de opdracht dit geld van har te besteden voor den aakoop voor har van het vee te zijner keuze. Heeft de boer het vee gekocht, dan moet hij een verklaring teekenen (strikt noodig is het niet, maar ik zal zoo dadelijk zeggen warom het beter is), dat hij voor de bank het vee in zijn bezit, houdt, totdat hij hetzij in eens hetzij in termijnen heeft afbetaald. Wil de boer verkoopen, dan moet hij daarvoor machtiging vragen van de bank: immers het is haar vee. Verkoopt hij $n u$, dan is hij haar mandataris of lasthebber en de opbrengst behoort, zoo althans niets naders is bepaald, weer ten volle aan de bank.

Ziedaar in grove trekken het plan dat, naar mijne meening, beter dan gewone geldleening de belangen waarborgt vau hem die de boer wil helpen en dus tegelijk eerder tot het verleenen van hulp zal genegen maken, terwijl aan den anderen kant de boer in zijn vrijheid niet binnen enger grenzen wordt beperkt dan eerlijkheid en goede trouw zelf hem stellen.

Waarom? Letten wij daartoe eerst op de positie der bank ${ }^{1}$ ).

1) Eenvoudigheidshalve noem ik den «contractant ter eenre» maar bank, hoewel natuurlijk ieder particulier of iedere vereeniging dergelijke contracten sluiten kan. Dat het voornamelijk vereenigingen zullen zijn die aldus hulp verschaffen, ligt in den aard 
Wij zagen hoe weinig waarborgen zij als geldsehietster heeft. Maar blijft zij eigenaar, dan treedt voor haar geld het vee in de plaats, terwijl ze als geldschietster slechts een ongerekte vordering had zonder eenig recht tegenover het voor haar geld gekochte vee. Betaalt dus de boer per slot van rekening niet, dan heeft zij bij hem op stal staan haar vee dat wel in de meeste gevallen ') meer waard zal zijn dan zij er aanvankelijk voor nitgegeven heeft, zoodat zij haar kapitaal met rente terugkrijgt en de rest aan den boer als belooning voor de aan het vee besteede kosten en arbeid kan teruggeven.

Het is waar, wanneer de boer een pachter is, dan is ook dat vee, hoewel het niet zij $n$ vee is, ouderworpen aan het voorrecht dat de verpachter als zoodanig heeft. Het klinkt wel zonderling dat een voorwerp dat niet aan den schuldenaar toebehoort en niet uitdrukkelijk voor diens schuld in pand is gegeven, aansprakelijk is voor de schulden van dien mau of liever voor een bepaalde soort van zijn schulden. Maar de wet geeft nu eenmaal zulk een onbillijk recht aan den verpachter en laat geen andere hoop over dan dat deze het beneden zijn fatsoen zal achten onder bescherming der wet een derde die hem niets schuldig is aftenemen hetgeen eukel dien derde toekomt ${ }^{2}$ ).

der zaak. Wellicht zou het vooral op den weg der Coöperatieve vereenigingen tot den aankoop van landbouwbenoodigdheden liggen ook in deze richting het terrein harer operatiën uit te breiden.

1) Natuurlijk daling van prijzen daargelaten. Brengt bij verkoop het ree niet eenmaal zooveel op als het gekost heeft, dan lijdt de bank en de boer ook schade. Maar dit is nooit te keeren, terwijl waar de bank enkel geldschietster is, haar positie in dergelijk geval nog ongunstiger is.

2) Men weet hoe de bepaling in de wereld kwam. De Code Civil kende znlk een vèrstrekkend roorrecht niet. Volgens art. $2102, \mathrm{~L}^{\circ}$, overeenkomende met de artt. $11854^{\circ}, 1186-1189$ van ons B. W., had de verhuurder alleen een recht op de goederen van den huurder. Slechts bij uitzondering was, naar art. 1753, de onderhuurder birnen bepaalde grenzen aan den verhuurder verbonden en kon deze (C. de Proc. civ. art. 820) ook op des onderhuurders goed in de gehuurde woning beslag leggen; terwijl art. 1813 aan den grondeigenaar het recht gaf aan te grijpen en roor zijns pachters schulden te verkoopen het vee dat floor een ander an dien pachter in huur (cheptel) gegeven was, mits die ander die 
Doch hoe dit ook zij, wannecr de bank eigenaar blijft van bet vee, dan is ze nooit in slechter conditie dar: wanneer ze enkel geldschieter is, want dan is hel vee warvoor het geld gesehoten is, natuurlijk eigendom van den boer en derhalve a fortiori onderworpen aan het voorrecht van den verpachter, die, hoe nanw zijn geweten ook is, er volstrekt geen bezwar in behoeft te zien zijn voorrang op de opbrengst bij executie te doen gelden.

Wat evenwel het voornaamste voordeel is bij den gewijzigden stand van zakeu is, dat de bank nu in veel gevallen den veehouder kan trekken voor den strafrechter en dat dus de bank daarin een waarborg voor de bewaring harer rechten krijgt, dien zij naar burgerlijk recht tegenover den in menig geval weinig solventen arbeider of kleinen boer - en juist voor zulken wordt naar hulp gezocht - vaak mist.

Art. 321 toch van het Wetboek van Strafrecht straft als verduisteraar hem die opzettelijk eenig goed dar geheel of ten

huur niet aan den eigenaar der pachthoeve had beteekend. Maar hij ons was men tijdens het maken der wet bang - en terecht voor ondergeschoven akten; de huurder zou immers den verpachter die zijn inboedel komt executeeren, een akte van verkoop kunnen voorhouden! En alsof nu dit de oplossing der moeilijkheid was, - een moeilijkheid trouwens die toch niet enkel met betrekling tot den verhuurder maar tot ieder schuldeischer diende opgelost te worden! - schreef men in de wet dat de verhuurder zijn voorrecht kan doen gelden op wat hij bij den huurler vindt, onverschillig wie er de eigenaar van is. Wat den gewonen schuldeischer, die beslag legt onder zijn schuldenaar en daarbij treft het goed van een ander, blootstelt aan een veroordeeling tot schadevergoeding wegens onrechtmatige daad (althans wanneer hij wist dat het niet het goed van zijn schuldenaar was), wordt voor den verhuurder tot wettelijk recht rerheven! Ja, hij mag niet alleen ongestraft beslag leggen maar executeeren ook!

Het nieuwe Duitsche Wetboek heeft het privilegie geheel tot de goederen des huurders beperkt ( $\$ 559$ ); zie de Motive II p. 404 v.; in aansluiting, naar aldaar wordt meegedeeld, aan de gevestigde jurisprudentie onder het Pruisische recht, al schijnt deze ook vroeger (zie Stall's Rechtsphilosophie II p. 381 noot) er toe te hebben overgeheld de minder duidelijke bepalingen van het Pruisiscine landrecht (I. 21 § 395 ) uit te breiden in den geest onzer wetgeving. 
deele aan cen ander tochehoort en dat hij anders dan door misdrijf onder zich heeft, wederrechtelijk zich toeëigeut. De straf is gevangenisstraf van ten hoogste 3 jaren of geldboete van ten hoogste $f 60$.- . Het is duidelijk dat waar do bank voorschotgever is, zij nooit door dat artikel kan beschermd worlen, want hanr voorschot wordt eigendom van den boer en dezo kau met zijn varken, dat hij van ziju geld kocht, doen wat hij wil.

Maar dit kan de boer, die vee vau de bank houdt, niet.

Stel dat nu de boer het vee aan een ander verkoopt zouder verlof van de bank, en het van dien ander in bruikleon houdt, - een maar al te dikwijls toegepast middel om crediteuren om de tuin te leiden, - dan zal de bank bij den Offieier van Iustutie klachte kunnen doen wegens verduistering; immers dat de boer door het stuk vee te verkoopen zich den eigendom daarvan toekende, of, zooals de wet zegt, zich dat toeëigende, en dat hij zulks doed zonder daartoe gerechtigd to zijn en dat hij zich ran dit alles wel bewust was, zal wel bij niemand twijfel ontmoeten.

Iletzelfde is het geval wanucer hij het vee ecnvoudig verkoopt zonder meer ') of het wegschenkt.

1) "Verkoopt», n.l. in den zin van het dagelijksch leven, niet in den juridischen zin, waarbij men enkel denkt aan het afsluiten van het koopcontract afgescheiden van de levering. Het enkele afsluiten van den koop wordt wel door sommigen (Mr. v. Ittersum in Tijdschr. v. Strafr. V. p. 342, Rechtb. Groningen W. $\mathrm{n}^{\mathrm{o}}$ 6554) als toeëigening beschouwd, doch, aangeuomen zelfs dat roor toeëigening niet meer noodig is dan eeen handeling in strijd met den aard ran zijn bezit», valt $\mathrm{m}$. i. hieronder het bloote verkoopen niet. Het afsluiten van een contract over een zaak verandert mijn verhonding tot die zaak niet in het minst. Moeilijker wordt het wanneer de houder met de zaak hij zich bv. van den eenen opkooper naar den anderen loopt (zie de ronnissen der Rechtbanken te Amsterdam en 's Gravenhage resp. in W. 6074 en 6918). Hier kwam wel zelfs het contract niet tot stand, laat staan de levering, doch men vergete niet dat de toeëigening bewezen moet worden en daarvoor zeer zeker de levering na koop afcloende is doch het bewijs dier toeëigening althans der poging daartoe ook kan voortvloeien uit andere daden die men met het 
Over verpauden bestaat verschil van meening, doch ik aarzel niet mij aan te sluiten bij de heerschende meening, volgens welke beleening onder omstandigheden waarin men weet niet terug te kunnen betalen, als een daad van toeëigening is te beschouwen. Welk karakter de in pandgeving draagt moet derhalve in ieder afzonderlijk geval onderzocht worden. Wanneer gij bijv. van daag in groote geldverlegenheid verkeerende een stuk van waarde dat uw vriend a toevertrouwde, beleent om aan geld te komen, terwijl gij weet dat gij over een paar dagen, wanneer uw coupons vervallen, ruimsehoots in staat zult zijn dat voorwerp weer in te lossen, dan kent gij u zeer zeker den eigendom van dat voorwerp niet toe, al maakt gij ook van de zaak een gebruik waartoe zij u niet gegeven is. Maar wanneer gij bij de beleening weet dat gij vóór het verstrijken van den termijn van inlossing, (als wanneer het goed onherroepelijk eigendom van den paudhouder wordt), niet in staat zult zijn het voorschot terug te betalen, dan bewijst uw handeling in verband met die omstandigheid dat gij niet enkel voor een oogenblik wildet profiteeren van de ruilwaarde die dat voorwerp had, maar dal gij die waarde voor goed in uw vermugen hebt overgebracht: $m$. a. w. dat gij $\mathfrak{u}$ dat voorwerp hebt toegeëigend. ${ }^{1}$ )

goed pleegt, uit de wijze waarop men met het goed omgaat. Het zich door levering na koop voor goed ontdaan hebben ran het bezit is dus wel eén der bewijzen van de plaats gehad hebbende toeëigening, doch niet het uitsluitende.

1) Zie het arrest van den Hoogen Raad in W. $n^{\circ}$ 5678. In een zeer belangrijk artikel in het Tijdschr. v. Str. VI p. 38 v.v. verdedigt Mr. H. P. de Wilde de leer dat verpanding van eens anders goed niet is verdnistering. Hij toont, geloof ik, zeer terecht aan dat het enkele doen van wat alleen de eigenaar doen mag geen toeëigening is: het vernielen, wegwerpen of verhuren eener zaak maakt den houder niet tot verduisteraar, hoewel de houder met de zaak handelt alsof het zijue eigene ware, en doet wat alleen de eigenaar mag doen. De handeling moet werkelijk dragen het karakter van zich den eigendom der zaak toekennen. Maar dit is onder omstandigheden ook de verpanding, [zeker niet het op aanvrage niet aan den eigenaar restitueeren, gelijk Mr. de W. meent op p. 59]. Dat dan het objectiere element van het misdrijf 
Welnu, dit laatste geval zal zich juist meestal voordoen bij diegenen voor wie reebankjes als ik op het oog heb bestemd zijn orn te werken: en mocht er al eens een welgestelde boer onder loopen, dan zal, ook al kan het Openbaar Ministerie niet het opzet der toeëigening bewijzen, de bank geen schade lijden, omdat zij met een civiele actie zich recht kan verschilfien.

$\mathrm{Nu}$ zal de strafactie op zich zelf aan de bank het haar onttrokker vee niet terugbezorgen: doch indien het vee nog te achterhalen is, heeft zij het recht het vee terug te koopen voor den prijs dien de houder betaald heeft, en indien deze op de terechtzitting als getuige verschijnt, zal met een enkel woord de zaak in het reine gebracht zijn zonder dat zij tot verdere moeilijkheden of zelfs tot een procedure behoeft aanleiding te geven.

In zooverre staat dus reeds de bank die eigenaar blijft in voorleeliger positie dan de geldschieter, want deze heeft zelfs niet dat beperkte vernogen (ul. van het vee te achterhalen). Maar, de groote veiligheid, aan de bank door de strafactie bezorgd, is hierin gelegen, dat zij aan een ieder die haar hulp verlangt, vermag voor te houden dat zij een zoo machtig wapen tot haar beschikking heeft; zoodat wie al in verzoeking mocht zijn oneerlijke handelingen te plegen, zich wel tien maal zal bedenken voor hij aan die booze verleiding het oor leent.

En wanneer dat zoo is, dan blijkt ook dat langs dezen weg

niet tot zijn recht zou kromen, zie is niet in. Werd toch roor de strafbaarheid vereischt dat de eigenaar het voorwerp niet meer kon terugkrijgen, dan ware het wat anders: doch dit gevolg is geen element van het misdrijf. De eenige vraag is hier, even als bij diefstal, wat toeëigening is: dit is het onttrekken aan den eigenaar. Of al met blijrend gevolg, is, ook evenals bij diefstal, onverschillig. Tegenover den dief heeft de eigenaar zeer zeker de revindicatie; toch eigende de dief zich toe. En dat de verpander, door terug te koopen, wanneer hij toevallig daartoe in staat geraakt, en door dan aan den eigenaar te restitueeren zijn daad ongedaan kan maken, is een opmerking die, ware zij juist, ook het misdrijf van diefstal onmogelijk zou maken, omdat de dief nog altijd het voorwerp op zijn plaats kan terugbrengen. 
bereikt kan worden wal men langs dien van het eenvoudige voorschot niet boreiken kon. $\mathrm{Nu}$ toch heeft men ook een middel tegen hen die men wegens hun onvernogen civielrechtelijk niet bereiken kin. Deze wijze van contracteeren geefl derhalve een sterken waarborg tegen kwade trouw, en maakt bovendien dat men niet gelijk de gewone geldschieter, bevreesd behoeft te zijn met andere schuldeischers de karige opbrengst der executie te moeten deelen, stel al dat er na aftrek der kosten nog iets te verdeelen mocht overblijven. En dus zal meu nu eerder menschen bereid vinden die hun geld durven toevertrou wen aau een bank die op dergelijke wijze haar zaken drijft, want bij het gewone voorschot moest zoowel de noodzakelijkheid met andere crediteuren in een schier waardeloos inboedeltje te concurreeren, als de warschijnlijkheid dat het uit dien hoofde toch nooit tot een executie zou komen, m. a. w. dat het geschoten geld eeuvoudig was a fonds perdu, en bovendien nog het gebrek aan bescherning tegen kwade trouw er van afschrikken geld to geven aan een instelling die voor dergelijke bezwaren stond.

Men verschaft dus door de bank eigenaar te laten, haar een alleszins rechtmatige zekerheid, dus ook aan hen met wier geld de bank moet werken, en geeft zoodoende ann het kapitaal eene schoone gelegenheid tot de behartiging van belangen die vroeger bij gebrek aan waarborgen onverzorgd bleven. Ook hier blijkt overtuigend hoe de mogelijkheid van een rechismiddel tege $\mathrm{n}$ den schuldenaar welbezien is in het belang van den schuldenaar zelven!

Het behoeft wel geen betoog dat hetgeen ik over de strafrechtelijke aansprakelijkheid ten aanzien van het net het geld der bank gekochte vee heb opgemerkt, evenzeer van toepassing is op het tot den aankoop daarvan verstrekte geld wanneer de boer die opdracht niet nakomt doch het geld voor andere doeleinden besteedt; ${ }^{1}$ ) en in gelijke mate op

1) Wel is van zeer bevoegde zijde volgehouden dat verduistering van geldsommen in de meeste gevallen niet mogelijk is omdat de lastgever bij het overreiken van het geld waarmeè zijn last moet worden uitgevoerd, daarvan tegelijk den eigendom overdraagt en de bewarnemer volgens het $B$. W. de bevoegdheid heeft andere 
het geld dat de boer voor het met machtiging der bank verkochte vee heeft ontvangen en dat althans voor een deel, aan haar toekonit. Natuurlijk zullen er gevallen mogelijk zijn warin die strafrechtelijke ansprakelijkheid geen effect sorteert omdat het bewijs niet te leveren is, maar dit neemt niet weg de praeventieve werking der strafbedreiging, en dat is juist een voorname kurk waarop dergelijke veebanken behooren te drijven. Ook dit was anders war de bank enkel geld schoot. Want ook al bepaalde zij, zooals te Zetten, dat het voorschot opeischbaar werd zoodra de boer liet geld niet vour het opgegeven doel besteedde, zon had zij daarmede toch niets anders dan eene civiele actie, en wat men daaraan heeft waar de Keizer ziju recht verliest, hehoef ik werkelijk niet meer te herhalen.

Zien wij thas op de positie van den boer die gebruik maakt van de hulp van de hank, en houden wij daarbij in het oog dat het doel moet zijn hem evenveel vrijheid zoowel ten aanzien der aanschaffing als ten aanzien van den eventueelen verkoop van het vee te geven, als wanneer hij enkel voorschot van de bank had gekregen en dus eigenaar van het vee ware geworden. Wij zullen hem daartoe volgen van af het oogenblik dat hij zich bij de bank aanmeldt totdat hij zich van al zijn verplichtingen heeft gekweten.

De boer begint dan met op zijn verzoek zooveel geld van de bank te krijgen als noodig is voor het vee dat hij koopen wil. Natuurijk is dit niet altijd van te voren met zekerheid

penningen in de plaats terug te geven, m. a. w. het depôt zich toe te eigenen, zoodat dan van wederrechtelijke toeëigening geen sprake kan zijn (Mr. Simons in T. v. S. III p. 289-307); doch het tegen deze bewering gerichte betoog van Mr. Besier, die $\mathrm{m}$. i. terecht in het enkele mandaat om te betalen geen eigendomsoverdracht ziet en ten aanzien ran de bewaargeving de min juiste, intusschen niet enkel door Mr. S. verdedigde opvatting van art. 1751 b B. W. weêrlegt (T. v. S. IV. p. 365-374), komt mij voor het onhoudbare van Mr. S's standpunt overtuigend te hebben aangetoond. Bovendien doet zich $\mathrm{m}$. $\mathrm{i}$. in het contract dat wij thans bezig zijn te beschouwen juist het geval voor, waarin zelfs Mr. S. geen bezwaar heeft verduistering aan te nemen (de nitdrukkelijke reserve van zijn eigendomsrecht door den lastgever). 
te bepalen, vooral niet wanneer het vee op de markt gekocht unoet wordeu, maar het zal wel nimuer veel moeite kosten ten naastenbij dit bedrag te bepalen.

Doch, letwel, hij wordt nu niet eigenaar van het geld doch gemachtigde, gemachtigde om voor de bank dat vee aan te koopeu, hetwelk vermeld staat in het geschrift dat van het contract gemaakt wordt.

Door hem aldus te laten optreden, wordt op krachtige wijze de verzoeking tegengewerkt om het geld voor andere doeleinden te besteden; het is niet $\mathrm{zijn}$ geld dat bij mede naar huis neemt en waarmeê hij ter markt gaat, maar het geld van de bank; hij mag het gebruiken, maar alleen voor het anngewezen doel; gebruikt hij het niet daarvoor maar voor andere dingeu, dan wordt hij strafrechtelijk ansprakelijk wegens verduistering. Dit was bij het gewone voorschot anders, gelijk wij zagen.

Tevens kan hij door met dit geld vee te koopen, dit vee nooit voor zich zelf verkrijgen maar bezit hij, zoodra als het ware dat geld in vee is veranderd, ook dit vee voor de bank.

Inn toch heeft hij de vrijheid om naar eigen kenze te koopen, zooals in het contract uitdrukkelijk moet worden gezegd.

Ter zekerheid echter van de bank alsook on den boer niet door een te lang bezit van dat vreemde geld in de verzoeking te brengen er voorloopig iets anders mede te doen, wordt teveus bepaald dat die volmacht binnen zekeren tijd verloopt, zoodat hij op den aaugewezen dag het vee moet hebben aangekocht en daarvoor de verklaring hebben geteekend warvan zoo aanstonds sprake zal zijn, of het geld ann de bank moet hebben teruggegeven. Het spreekt van zelf dat het vall omstandigheden af hangt hoe lang die termijn moet genomen worden, loch het verdient aanbeveling dien als regel slechts zeer enkele, desnoods een of twee dagen te laten duren.

T'en einde allerlei omslag te vermijden, verbouden an de formeele in verzuimstelling wanneer het contract daar niet in voorziet, wordt bepaald dat de boer die het geld niet voor den veeaankoop besteedde, bij het verstrijken van den termijn es ipso in verzuim is.

Dit, als het ware preliminaire, contract kan niet gemist worden: het treedt in de plaats van de geldleening en beoogt hein dezelfde vrijheid te laten alsof hij slechts een voorschot had 
ontvangen. Men zou toch kunneu vragen of het niet eenvoudiger ware dat de bank zelf het vee kocht, en niet de boer voor haar als haar lasthebber. Doch het antwoord op die vraag zou zijn dat dit in de meeste gevallen èu voor de bank èu voor deu boer te bezwareud en te omslachtig zou ziju; immers zou dan, wanneer het vee ter markt moet gekocht worden, wat niet eens altijd het geval is, - steeds een bestuurslid der bank tegenwoordig moeten zijn, en verder zal wel in de meeste gevallen de ander zelf willen kiezen.

Heeft nu de boer het vee gekocht, dan gaat hij naar de bank en geeft het geld dat hij mocht overgehouden hebben aan haar terug; hij teekent daarbij tevens eene verklaring dat hij het dan daarin speciaal aangeduide en omschreven vee op de in die verklaring vermelde voorwaarden voor de bank in zijn bezit houdt, terwijl hij ten aanzien van het hem oorspronkelijk ter hand gestelde geld wordt gedéchargeerd.

Het teekenen dier verklaring is noodig om den boer nog eens goed in te scherpen dat hij niet eigenaar van het vee is en dus niet alles mag doen wat aan een eigenaar zou toestaan "). Aanvankelijk had ik gemeend dat ter vermijding van omslag hij die verklaring wel bij het oorspronkelijk contract zou kunuen teekenen, m. a.w. dat in én stuk zouden worden opgenomen de machtiging tot den aankoop van vee, de inbezitstelling van dit vee en de voorwaarden aan dat bezit verbonden; doch zoowel ter voorkoming van chicanes als om ook voor den boer alles weg te nemen wat hem zijn positie minder duidelijk zou kunnen maken, geef ik aan twee contracten de voorkeur. Onslachtiger wordt trouwens de zaak ook niet, want het is volstrekt niet noodig dat de man zijn verklaring gaat teekeneu ten kantore van de bank; deze kan immers hare bestuursledeu machtigen die verklaringen bij zich aan huis te lateu teekenen zoodat de boer gaat naar het lid dat het dichtst in zijn buurt wont.

$\mathrm{Nu}$ heeft hij dus het vee. Maar onder welke voorwarden heeft hij het? En hiermede stran wij voor een paar moeilijke vragen.

1) Om hem dit nog duidelijker te maken zou het misschien zelfs aanbereling verdienen, art. 321 van het Wetb. v. Sr. (betreflende de rerduistering) onder de contracten af te drukken. 
Voor de regeling der voorwaarden hebben wij te letten ìn op de soort van vee èn op het doel waarvoor hij hot vee heeft willen hebben.

Wat het laatste aangaat, zoo kan hij het noodig hebben om het te fokken en later met winst te verkoopen of om het te behouden bv. als melkvee. Wordt het nu enkel voor deu haudel aangekocht, dan is het, strikt genomen, niet noodig dat liij er vóór hij het weder verkoopt, eigenaar van wordt, want als hij behoefte heeft het vee bv. na een maand of tien te verkoopen, dan kan hij, zooals wij striks zullen zieu, aan de bank permissie vragen dit voor haar te mogen doen, en hetgeen hij boveu zeker bedrag er van maakt, als winst in ziju zak te steken. In het audere geval is ziju doel natuurlijk allengs eigenaar te wordeu.

Ook, zeide $i k$, moet gelet worden op de soort van vee. Betreft het toch bv. varkens, dan is de prijs zoo gering dat de bepalingen die bij duurder vee nuttig en noodig zijn, hier tot ongewenschten omslag zouden aanleiding geven.

Al naar zich dus de behoefte doet gevoelen, raakt men van den boer een bruikleener, of laat hem een afbetalingscontract sluiten, welks einddoel is hem eigenar te maken, terwijl dit met het bruikleencontract niet per se het geval behoeft te zijn.

a. Krijgt hij nu het beest in bruikleen, dan moet worden bepaald hoe lang dit duren zal. Want aan de eeue zijde moet de bauk niet naar willekeur het dier terug kunnen nemen, en aan de andere zijde moet het niet in de macht van den boer staan de bruikleenverhouding tot in het oneindige te rekkeu. In dat stuk vee toch steekt een deel van het kapitaal waarmede de bank haar zakeu-drijft; op een zekeren tijd moet de bank dit dus weer net zekere rente terug ontvangen. Verkoopt nu de boer het met consent van de bank, wanneer het voldoende gefokt is, dan loopt de zaak van zelf. Maar verplicht tot verkoopen is hij niet, en zoo zou hij dus bet varkeu rustig bij zich kunnen houden. Daarom staat in het contract dat de bank op een bepaalden datum het recht heeft het vee terug te nemen, doch tevens dat de boer het recht heeft tegen betaling van een zekere som (zijnde het voor het vee besteede geld vermeerderd wet de reute over den tus- 
schentijd) ${ }^{1}$ ), het dier voor zich zelven te koopen, hetzij hij dit doet omdat hij het blijvend houden wil, hetzij omdat hij beter narkt wil afwachten. Die datum moet zoo ruim gesteld zijn dat de boer, die het varken kocht om het te verkoopen, vóór de verschijning van dien dag de gelegenheid kan hebben gehand het van de land te doen. Doch het kan zijn dat die gelegenheid zich nog niet voordeed maar weldra verwacht wordt; uit dien hoofde moet hem het recht gegeven worden op een uitstel van één, desuoods twee maanden, waarvoor hij aan de bank, die gedurende dien tijd haar kapitaal moel missen, een kleine vergoeding geeft, berekend naar de rente die - had men met een zuiver voorschot te doen - over dien tijd betaald zou moeten worden.

Wil hij nu gedurende de bruikleenverhouding het vee verkoopen, dan moet hij, zooals ik zoo even zeide, verlof van de bank hebben. Onder welke voorwarden zij dit geeft zullen wij zoo aaustonds zien. Eerst moet ons bezig houden het geval

b. de boer krijgt het vee op afbetaling.

Bij velen staat deze wijze van contracteeren in eeu slechten reuk. Er zijn strekeu van Duitschland waar, (naar het oordeel althans door sommigen uitgesproken 0 . a. op den Verbandstag der Hess. Genossenschaften in 1892), juist dit de vorm is waarin veewoeker gedreven wordt; en al moge op dit gebied in Nederland dit contract nog weinig ingang gevonden hebben, op auder gebied zijn ze bekend genoeg, manr genieten alles behalve ieder's syıpathie.

Fin te recht. Degeen die het goed op afbetilling nremt, is an lianden en voeten gebonlen overgeleverl aan le bou vouloir van den credietgever.

Op het evengenoende congres werl o. a. gewezen op den truc dat, watr het vee bv. in 5 termijuen inot worlen albetaald, het altijd (i) zoo worlt geregeld dat de $1^{\text {c }}$ terwijn

1) Dit verhindert in het minst niet een zuiver bruikleen te zien in het onderhavig contract. Dit toch houdt daardoor niet op «om niet" te zijn, wat art. 1777 B. W. als essentiale van de overeenkomst van bruikleening voorschrijft. Verkiest dle boer het varken niet voor zich te koopen, lan neemt de hank het eenrondig terug, zonder dat de boer voor den tijd dat hij het hield iets an haar behoeft te betalen.

ECıN. 1897. 
vervalt op het oogenblik waarop de koe pas aan het melken is en juist gekalfd heeft; de man kan dan niet betalen en de koe komt bij den handelaar terug en daar de boer toch een stuk vee noodig heeft, krijgt hij een auder in ruil. Het rolgend jaar gebeurt hetzelfde en zoo kout de man steeds dieper in de schuld.

Doch afgezien van dergelijke slimheden bij het sluiten van het contract, geeft het contract den eigenaar-schuldeischer een wapen in handen warmede hij diepe wonden kan slaan.

Natuurlijk is een der voordeelen die het contract hem verschaft, dat hij nu een strafrechtelijke vervolging wegens verduistering uitlokken kan wanneer de houder het goed vervreemdt vóór de volledige afbetaling; hierop echter valt geen aanmerking te maken: hier is het geheel van de eerlijkheid van den houder afhankelijk of hij zijn vingers zal branden of niet.

Maar anders staat de zaak, waar afgescheiden vau eenige kwade trouw ann de zijde van den houder de richtige nakoming van het contract wordt verhinderd. Zoodra toch de vervalleu termijn niet betaald wordt, heeft gelijk in vele dier contracten bepaald wordt, de eigenaar het recht het goed weder tot zich te nemen, zoodat, wanneer bv. alle termijnen op één na betaald zijn, de schuldenaar die niet bij machte is bij de verschijning van dieu laatsten termijn terstoud te betalen, moet toezien dat men hern het goed, dat bijna zijn eigeudom was geworden, uit zijn huis haalt. Ik zeg niet dat ieder schuldeischer bij zulke contracten op zoo woekerachtige wijze gebruik maakt van zijn dusgenaamd recht, en ik weet ook wel dat dergelijke bevoegdheden moeten dienen om den schuldenaar tot regelmatige afbetaling te prikkelen, maar de klachten zijn niet zeldzaam dat op dergelijke wijze de aspirant-eigenaar aan het kortste eind trok. En wanneer men dat recht des schuldeischers dau verdedigt met een beroep op het karakter vau hu u r dat deze contracten dragen, (men spreekt in die contracten dan ook gaarne van verhuurder, en huurtermijnen!), dan vergeet men dat het afbetalingscontract daar al zeer weinig mede gemeen heeft. In de termignen die iedere maand betaald moeten worden, moge al een klein deel huur zijn, op die huur komt een groote toeslag die een deel is van het kapitaal zelf dat bij gedeelteu betaald wordt, en viet de rente er vall. De zgn. 
huurder betaalt bij iederen termijn dus veel meer dau enkel voor het gebruik, en, moet hij ua eenige betalingen gedaan te hebben zonder eenige schadeloosstelling het goed teruggeven eenvoudig omdat hij niet verder betaalt, dau wordt hij op onrechtvaardige wijze beuadeeld. Daarom komt het mij ook billijk en rechtvaardig voor dat de Duitsche wet op de afbetalingscontracten van 16 Mei 1894 bepaalt dat wanneer de schuldeischer op grond van het niet nakomen der verplichtingen aan zijde vau den schuldenaar, op het contract wil terugkomen, hij an de andere partij, uatuurlijk behoudeus zijn recht op vergoeding der schade, moet teruggeven de door haar gedane afbetalingen eu dat de contractueele bepaling vau het tegendeel nietig is.

$W_{\text {ij }}$ missen echter een dergelijke regeling en het is dau ook alleszins begrijpelijk dat bij velen onzer weinig ingenomeuheid met deze contracten bestaat. Toch vergete men niet dat ze in goede handen, en met oordeel des onderseheids gebruikt, vau onberekenbaar nut kumnen zijn '), daar zij de gelegenheid om de oeconomische voordeelen van een zaak te trekken geven an heu die daartoe anders niet in stant zouden geweest zijn

1) Wanneer twee hetzelfde doen, dan is lat daarme $\hat{\beta}$ nog niet hetzelfde. De waarheid hiervan komt bij ons onderwerp duidelijk aan het ljcht. Een zelfde contract kan in het eene geval voor den boer zijn ondergang zijn, in het ander zijn voordeel, en veel is hier af hankelijk van de moraliteit der wederpartij.

Op het hiervoren reeds genoemde congres der Hessische lamiw. Genossenschaften in 1892 werd een feit genoemd dat dienaangaande beter spreekt dan lange betoogen. Vooral in de arme streken der Rijnprovincie werd, naar de mededeeling van Dr. Havenstein (Bonn) op dat congres, steen en been geklnagd over de Vieheinstellung, doch wat men ook probeerde, niets hielp; totdat eindelijk eenige vereenigingen besloten, dezen handel zelf te gaan drijven! «Sie machen, regt dan Dr. H., das Geschäft nun genan so, wie es früher die Vieheinsteller machten, und die Erfolge tie sie dadurch gemacht haben, sind ganz erstaunliche. Der Umsatz beziffert sich in einzelnen Kreisen und zwar in den allerärmsten auf Millionen... Der Vortheil, den früher der Wucherer hatte, fliesst also in die Kreiskasse und kommt wieder den einzelnen Nitgliedern 31 Gute.» 
en die nu uit de vruchten die de zaak oplevert de middelen vinden die zaak tot een eigen bedrijfskapitaal te maken.

En nu kan ik mij juist niet voorstellen dat veebaukjes of andere landelijke inrichtingen die van deze contracten gebruik maken, dit zouden doen bezield door een geest van woeker. Men zal ook zien dat in de uitwerking van het contract alles vermeden is wat dien geest zou kunnen bevorderen.

Ik ben hier genaderd tot de vraag hoe nu de bank de afbetaling regelen en de afbetalingssom vaststellen noet. Bij deze berekening ben ik uitgegaan van de onderstelling dat de bank, trad zij zuiver als geldschietster op, zou berekenen een rente van 1 pCt. per maand. Deze rente is schijnbaar hoog, men zou haar dus ook lager kunnen stellen; alleen, ik heb bij het aaunemen van dezen rentevoet gelet op wat feitelijk hier en daar bestoud en van het gebruik maken der gelegenheid niel afschrikte, terwijl ik de rente mede zou willen doen strekken ter betaling der verzekering van het vee '). Men

1) Waartoe ik gaarne zou willen dat men hoe langer zoo meer overging. Vooral in de laatste jaren ontwikkelt zich de veeverzekering die vooral voor kleine boeren van het allergrootste belang is, ten onzent sterker. In het jongste Landbouwverslag (1895. $2^{\mathrm{e}}$ ged. p. 276-321) vonden voor 1892 en 1893 resp. ongeveer 338 en 378 veefondsen vermelding, welke eijfers echter reeds toen niet met de werkelijkheid overeenstemden en nu door een aanmerkelijk hooger cijfer worden overtroffen. Met uitzondering van zeer enkele onderlinge maatschappijen die over een groote uitgestrektheid ( 3 provinciën of meer) werken, zijn de meeste veefondsen locale vereenigingen, die intusschen zoowel wat de ziekten waartegen alleen, of waartegen niet verzekerd wordt, als wat de premiebetaling en het bedrag der nitkeeringen aangaat, een bonte verscheidenheid vertoonen. Inderdaad schijnen mij de moeilijkheden, aan de veeverzekering meer dan aan die tegen brand eigen, als welke gelden de groote gevaren roor kwade trouw en van nalatigheid, de moeilijke controle, de bezwaren bij het bepalen der identiteit, en de regeling van den omvang der aansprakelijkheid - het best door onderlinge kleine, locale vereenigingen te overwinnen. Deze toch zijn niet gebonden aan het in dezen zeker niet gevaarlooze agentenstelsel, en zijn door de beperktheid van het terrein in staat een scherpe controle te oefenen, waartoe de ansprakelijkheid voor de verliezen van anderen bij voortduring 
moet verder $\mathrm{m} . \mathrm{i}$. ook vooral niet bij cen eerste proefneming beginuen met de rente die, om de geringheid der benoodigde ankoopgelden toch nooit groote sommen kan beloopen, te laag te stellen, omdat men de rente later gemakkelijker verlagen dan verhoogen kan; terwijl ook op het einde van het jaar aan de deelnemers een zeker deel der winst naar rato der betaalde rente kan worden uitgekeerd.

Welke zijn nu de verplichtingen van den boer die het vee op af betaling ontving?

Ik stel mij dit nu zoo voor dat hij zijn termijnen bij vooruitbetaling voldoet, m. a. w. dat hij, stel dat het maandelijksche termijnen zijn, zijn recht op het bezit van het vee gedurende een maand ontleent aan het bij het begin dier mand betaald bedrag. De vooruitbetaling verdient hierom boven de nabetaling de voorkeur, oradat men.er moeilijkheden mede voorkomt; al de last eener outbindingsactie wordt er door gemeden; het bezit van iedere maand kan niet beginnen vóór de daarop vallende termijn is betaald, wordt m. a. w. afhankelijk gemaakt van de vervulling eener voorwaarde.

De som nu, die de boer in het geheel moet betalen om het

opwekt. Wanneer zij dan.ook met voorzichtigheid de anusprakelijkheid regelen, zooveel mogelijk van ieder lid het geheele beslag verzekeren, nooit de volle doch slechts een deel der getaxeerde waarde uitkeeren, en trachten spoedig een reserve te maken, kunnen zij veel nut om zich verpreiden. Het is waar, hoe kleiner het terrein, hoe grooter het risico, doch hiertegen vermag veel het maken van een zooveel mogelijk uniforme regeling der onderscheidene fondsen, om deze alsdan te organiseeren tot een bond, waardoor de verliezen van ieder fonds voor een deel (bv. $\frac{3}{4}$ of $\frac{4}{5}$ ) over de andere worden omgeslagen.

Coöperatieve aankoopvereenigingen, die op de hier door mij voorgestelde wijze den veeaankoop zouden willen bevorderen, zouden tevens de oprichting dezer veefondsen in de hand kunnen werken. Zij zouden misschien ook het vee bij zich zelven kunnen verzekeren, doch dit zou haar eigen administratie in rele gevallen boven de beschikbare krachten gecompliceerd maken; beter schijnen mij aparte fondsen, waarin dan de veehouder, zoodra hij van het vee eigenaar is geworden, als deelnemer optreedt in de plaats der vereeniging die hem het vee op afbetaling verschafte. 
vee in eigendom te verkrijgen hangt natuurlijk af van den $d$ u u $r$ der af betaling. Is de dunr bv. een tijd van 10 maanden dan moet de afbetalingssom - altijd in de veronderstelling dat men, als het een zuiver voorschot gold, 1 pCt. p. m. zou berekenen - ongeveer 5 pCt. zijn boven het bedrag dat voor den aankoop van het vee is besteed.

Immers laat ons voor een oogenblik aannemen dat inderliaad een voorschot gegeven was dat in 10 maandelijksche termijnen zou afbetaald moeten worden, dan zou dit de volgende berekening geven:

Van het op 1 Januari verleend voorschot van f 100 wordt betaald

op 1 Februari f 10 met 1 pCt. over f $100=f 11$ -

op 1 Maart f 10 " 1 pCt. " f $90=\mathrm{f} 10.90$

op 1 April f $10 " 1$ pCt. "f $80=$ f 10.80

enz.; zoodat op 1 November betaald is $f 100$ met aan rente f 4.50 welk laatste bedrag men voor de eenvoudigheid naar boven kan afronden tot $\mathrm{f}$ 5.-.

Dit op het afbetalingscontract overbrengende, krijgt men een af betalingssom van f 105 warvan de maandelijksche termijneu bedragen $\mathrm{f} \mathbf{1 0 . 5 0}$.

Wanueer men het evenwel den boer zoo gemakkelijk mogelijk wil maken, d. w. z. hem zooveel mogelijk de voordeelen wil laten behouden die aan een zuiver voorschot verbonden ziju, waarbij hij wel in de meeste gevallen korter of langer uitstel vau betaling van een termijn zal kunnen verkrijgen zonder dat daarmede terstond de geheele schuld opvorderbaar wordt, dan moet men hern ook hier de gelegenheid geven een enkel maal de betaling van den termijn een maand te verschuiven. Opdat echter de bank hierdoor geen schade lijde, moet zij voor dat uitstel berekenen bv. I pCt., wat zij ook zou berekend hebben wanneer zij aan den man een voorschot gegeven had en hij om uitstel was komen vragen. Ook omgekeerd kan men den boer I pCt. laten aftrekken voor iedere maand dat hij een termijn vroeger betaalt dan hij moest. Om hem een prikkel tot sparen te geven en tevens het risico der bank te verminderen verdient dit zelfs alleszins aanbeveling.

Edoch, om op het verleeuen van uitstel nog even terug te komen, te veel moet men dartoe niet de gelegenheid geven; 
de bank moet niet aan het lijntje gehouden worden doordat de boer die bv. nog 9 termijnen van $\mathrm{f} 10.50$ schuldig is, haar alle maanden een sommetje van f 0.94 .5 ( 1 pCt. van de 9 nog verschuldigde termijnen) komt brengen. Is het uitstel bv. tweemaal verleend, dan moet zij het recht hebben op het contract terug te komen, en het stuk vee tot zich te nemen.

Ten einde nu evenwel te voorkomen de onbillijkheid waarop ik zoo straks wees, dat nl. door de bloote terugneming van het vee zonder eenige restitutie, de bank zich op onredelijke wijze zou verrijken, moet zij althans een deel der betaalde termijnen teruggeven; niet het volle bedrag der betaalde termijnen, want dat zou tot misbruiken aanleiding geven, terwijl het bovendien niet onmogelijk is dat zij, bv. doordat zij op ongelegen tijden met vee blijft zitten, schade lijdt. Om alle gekibbel over het al of niet lijden van schade en over de hoegrootheid daarvan af te snijden, is het daarom het beste vooraf vast te stellen dat, indien de bank het vee terugneemt, bv. de helft of eeu derde der reeds betaalde termijnen zal worden gerestitueerd.

$\mathrm{Nu}$ bestaat echter ook de mogelijkheid dat het vee tusschentijds komt te sterven. Het komt mij voor dat het billijk en ook praktischer is dat de bank dan de schade draagt. Zij kan zich trouwens daartegen verzekeren. Doch dan houdt ook van zelf de verplichting tot betaling der verdere termijnen op, en moet alles wat de boer betaald heeft aan hem worden teruggegeven: hierbij wensch ik geen splitsing te maken tussehen de huur en den toeslag welke laatste dient tot de verkrijging van den eigendom, en wensch ik niet dat de bank alleen dien toeslag teruggeeft; want men moet niet vergeten dat, vooral wanneer reeds de meeste termijnen betaald zijn, de arbeid van den boer de warde van het vee in vele gevallen aanmerkelijk zal hebben verhoogd, en de bauk daar dus feitelijk het profijt van trekt. Mocht dit profijt inderdaad zoo groot zijn dat de assurantiepenningen het voor den aankoop besteede bedrag eenigszins belangrijk overschreden, dan geloof ik dat de bank verstandig zou doen ook dit meerdere den man uit te keeren; hiervan een uitdrukkelijke bepaling in het contract op te nemen acht ik echter niet noodig.

Tot verzekering van haar rechten kan de bank bepalen dat 
het op de hier omschreven wijze iangekochte vee moet worden ge merkt. Bepaalt zij dit, dan moct zij wanneer zij eventueel verlof geeft het vee te verkoopen, dit weer "vrij" maken.

Het is evenwel niet onmogelijk dat men bij de boereu zelf hezwaren tegen die merking ontmoet, omdat ze min of meer het karakter van wantrouwen draagt: daarom zou men kunnen volstaan met daar de merking te verlangen waar de boer ook vee van zichzelf op stal heeft staan; en in een zoodanig geval is dit verlangen dan ook alleszins gewettigd; terwijl, waar het zulke kleine veehouders betreft die hun vee alleen met behulp van de bank hebben verkregen, het bewijs der verduistering in den regel wel zoo gemakkelijk te leveren zal zijn dat men daarvoor de merking niet noodig heeft. Het is waar, zonder merking raakt men het spoor van het verduisterde vee zeer spoedig kwijt, doch of merking tegenover den derden houder heel veel rechten geeft meen ik te moeten betwijfelen; het zou mij evenwel te ver voeren hierover uit te weiden.

Nog één punt blijft rijj in dit verband over om te bespreken. [ $\mathrm{k}$ bedoel $\mathrm{nl}$. den verkoop van het vee vóór het oogenblik dat de boer er eigenaar vall geworden is. Dit puut is niel zonder belang omdat juist met het oog op dien verkoop het, vee in vele gevallen wordt ailugeschaft.

Het sprcekt van zelf dat de boer voor dien verkoop permissie moet hehben. Men zou kunnen vragen of hij niet tot dien verkoop gemachtigd zou kunnen worden tegelijk in et het hem ter hand stellen van het geld voor den ankoop van het vee, althans bij het contract waarbij hij het vee in bruikleen of op afbetaling krijgt. Ik geloof evenwel niet dat dit aanbeveling verdient. Het zou wel niet alle voordeelen opheffen die aan dezen vorm van hulp verbonden zijn, daar toch het vee, zoolang het onverkocht is, blijft het eigendom van de bank en dus - met uitzondering van het voorrecht van den verhuurder (zie bl. 525) - onttrokken is aan het verhaalsrecht van de crediteuren van den boer; maar de groote waarborg dien deze vorm oplevert tegen kwade trouw aan de zijde van den boer zelf, zou er dunkt mij door verdwijnen, omdat deze zou kunnen antwoorden wanneer hem naar het dier gevrangd werd, dat hij het al lang had verkocht daar hij immers door de bank zelf gemachtigd was het te verkoopen. 
Daarbij heeft bij de afzonderlijke, latere machtiging, de bank het voordeel gemakkelijker te kunven weten waar het vee blijft en wat het opbrengt, en kan zij haar voorzorgen nemen dat de koopprijs die de boer ontvangt niet langer dan noodig is in zijn handen blijft. Zoodoende ook is, wauneer hij het geld niet afdraagt, de nogelijkheid van een strafrechtelijke vervolging ter zake van verduistering niet uitgesloten.

Omslachtig is deze afzonderlijke inachtiging niet, vooral niet wanneer men ook hier weder bepaalt dat een enkel bestuurslid die machtiging kan uitreiken, en de veehouder dus niet gedwongen is naar het kantoor der bank te gaan. Meestal zal het vee ter markt verkocht worden, en dan kan men voor dien specialen marktdag de machtiging geven, zoodat hij des avonds of het geld of het vee moet toonen. En wordt het dier op stal verkocht, dan geschiedt de levering, in vele gevallen ten minste, toch eerst den volgenden dag, zoodat de veehouder de gelegenheid heeft in dien tusschentijd de machtiging te gaan vragen.

Hiermedc heb, naar ik mij vlei, de zaak van alle zijden bezien en geen bezwaren onbesproken gelaten die bij den eersten anblik zouden kunnen rijzen. Heb ik mijn doel bereikt, dan is de lezer overtuigd van het groote belang der vrang van doelmatiger hulpverschaffing bij den ankoop van vee, en is hij tevens gewonnen voor de hier voorgestelde oplossing. In ieder geval zou het mij eene voldoening zijn, indien deze regelen aanleiding mochten geven de kwestie in welke richting dan ook een schrede nader tot haar oplossing te brengen.

's Gravenhage. W. H. de Sarornin Lohman. 
Bijlage.

CONTRACT A.

tusschen de Vereeniging . . . . .

en

.... van beroep.... te. . .

ART. 1. De $2^{e}$ ondergeteekende ... verklaart op . . 18 . . van de $1^{\mathrm{e}}$ onderget., de Vereeniging, ontvangen te hebben de som van $f \ldots$ om daarmede vóńr . . 18 .a) voor de Vereeniging te koopen .... naar zijne, des $2^{\text {en }}$ onderget., kenze.

A Rr. 2. De $2^{\mathrm{e}}$ onderget. is zonder nadere in verzuim stelling verplicht op ...18 .b) het ontrangen bedrag aan de $1^{\mathrm{e}}$ onderget., die daarvan eigenaar is gebleven te verantwoorden.

Hij verbindt zich daarbij tevens aan de $1^{e}$ onderget. nauwkeurig op te geven welk vee hij heef aangekocht en roor welk bedrag, met teruggave van hetgeen van het in art. 1 genoemd bedrag mocht zijn overgebleven; en daarbij een contract te teekenen houdende de nadere voorwaarden waarop $\mathrm{hij}$ dat vee voor de $\mathfrak{l}^{\mathrm{e}}$ onderget. onder zich hondt.

Bij gebreke hiervan heeft de $1^{\mathrm{e}}$ onderget. het recht het aangekochte vee onmiddellijk op te vorderen.

CONTRACT B.

tusschen de Vereeniging .....

en

$$
\text { .... van beroep . . . . te . . . }
$$

ART. 1. De $2^{e}$ onderget. verklaart van af heden onder zich te hebben een ...., zijnde dit vee voor de $1^{\mathrm{e}}$ onderget. met haar geld aangekocht en aan haar toebehoorende; waartegenover de $1^{\text {e }}$ onderget. hem ontslaat van alle verplichtingen voortvloeiende uit het tusschen hen gesloten contract (A) van ... 18 . .

ArT. 2. Hij verbindt zich voor het gebruik van dit vee en ter verkrijging van den eigendom hiervan, bij vooruitbetaling in 10 maandelijksche termijnen van $f \ldots c)$, en bij uitstel dezer maandelijksche af betalingen aan de $1^{e}$ onderget. bovendien en zonder dat daartoe eenige in verzuimstelling noodig zij, te vergoeden $1 \mathrm{pCt}$. p. maand over het nog verschuldigd bedrag.

ART. 3. Wanneer de $2^{\mathrm{e}}$ onderget. 2 achtereenvolgende maanden in gebreke blijft met de afbetaling, heeft de $1^{e}$ onderget. bet recht

a) in te vullen zulk een datum dat de aanvrager één of meer dagen heeft voor den aankoop, zooveel tijd dus als het bestuur in ieder afzonderijk geval noodig en gewenscht oordeelt.

b) in te vullen den in art. I laatstgenoemden datum.

c). Vergelijk hicrbij bl. 538 , v.v. 
het vee terug te nemen onder gehoudenis van teruggave van $\frac{1}{2}$ der reeds betaalde termijnen.

ArT. 4. Hij heeft het recht meerdere of alle termijnen tegelijk te betalen, in welk geval hij bij iederen termijn $1 \mathrm{pCt}$. kan aftrekken roor iedere maand die hij dien termijn te vroeg betalt.

ArT. 5. Het is den $2^{\text {en }}$ onderget. uitdrukkelijk verboden het vee (dat aan de Vereeniging toebehoort) te verkoopen, weg te schenken, te verpanden of in bruikleen te geven. Het ree blijft in geval van faillissement van dien onderget. buiten diens boedel.

De $2^{\mathrm{e}}$ onderget. is verbonden voor het vee behoorlijk zorg te dragen.

A RT. 6. Op het oogenblik dat de laatste termijn is betaald, wordt de $2^{\mathrm{e}}$ onderget. eigenaar van het vee.

ART. 7. Komt het vee tusschentijds te sterven, dan houdt de verplichting tot betaling der verdere termijnen op en worden, wanneer aan den $2^{\text {en }}$ onderget. geen schuld te wijten is, de reeds betaalde termijnen na aftrek ran 3 pCt. aan hem terug gegeven.

A RT. 8. De $2^{\mathrm{e}}$ onderget. is verplicht het bestuur der Vereeniging of zijn leden te allen tijde op zijn erf of land toe te laten, en het vee van wege de $1^{\mathrm{e}}$ ondergeteekende te laten merken indien dit harerzijds verlangd wordt.

\section{MACHTIGING TOT HET VERKOOPEN VAN VEE.}

Het bestuur der Vereeniging . . . . . .

machtigt bij deze ..... om voor haar het haar toebehoorend zich onder hem bevindend vee, met name .... (waarop betrekling heeft het contract $B$ van $\ldots 18 \ldots n^{0} \ldots$ te verkoopen voor een bedrag ran $f$...

hetgeen hij zich verbindt aan het bestuur onmiddellijk na den verkoop, immers niterlijk op ...18 . af te dragen, zullende hij bij het verstrijken van dien termijn zonder nadere in gebreke stelling in verzuim zijn.

Tusschen partijen is overeengekomen dat hetgeen hij,... boven het zooëven genoemd bedrag voor het vee ontrangt, niet aan het bestuur behoeft te verantwoorden.

Opmerking. Maakt men van het contract van bruikleening gebruik, dan worden de met de afbetaling in verband staande bepalingen vervangen door de volgende:

"De $2^{e}$ onderget. houdt het voor de $1^{e}$ onderget. aangekochte en aan deze toebehoorend ree in bruikleen tot.... 
Heeft hij niet voor of op dien dilg machtiging ontvangen het vee te verkoopen en daaraan gevolg gegeven, en heeft hij evenmin gebruik gemaakt van de hierna te melden bevoegdheid, dan heeft de onderget. het recht het ree terug te nemen of zelf te verkoopen.

De $1^{\mathrm{e}}$ ondergeteekende geeft alstan aan den $2^{\text {en }}$ onderget. de waarde die op dat oogenblik naar de meening ran het bestuur dat vee heeft, of datgene wat het bij verkoop opbrengt; alles evenwel na aftrek van het voor den aankoop besteede geld vermeerderd met zooveel maal $1 \mathrm{pCt}$. van dit bedrag als er maanden verstrijken tusschen den dag van dit contract en den hierboven genoemden datum.

De $2^{\mathrm{e}}$ onderget. heeft de beroegdheid het vee van de $1^{\mathrm{e}}$ onderget. af te koopen door betaling van het voor den ankoop besteede geld met zooveel maal $1 \mathrm{pCt}$. als maanden zijn verloopen tusschen den dag van dit contract en dien waarop hij het vee van de vereeniging afkoopt.

Komt het vee buiten de schuld van den $2^{\mathrm{en}}$ onderget. tusschentijds te sterven, dan houdt iedere verplichting zijnerzijds op.» 